\title{
Spore Germination of Gleichenella pectinata (Willd.) Ching (Polypodiopsida-Gleicheniaceae) at Different Temperatures, Levels of Light and pH
}

\author{
Eunice Pereira Gonçalves dos Santos, Débora Rosana Marques Lehmann; Marisa Santos \\ and Áurea Maria Randi* \\ Laboratórios de Anatomia Vegetal e Fisiologia Vegetal; Departamento de Botânica; Centro de Ciências \\ Biológicas; Universidade Federal de Santa Catarina; Campus Universitário Trindade; 88040-900; Florianópolis - \\ SC - Brasil
}

\begin{abstract}
This study investigated the effects of different temperatures (25 and $\left.30 \pm 2{ }^{\circ} \mathrm{C}\right)$, light levels (62, 42, 22 and $5 \%$ of natural light), and $\mathrm{pH}$ (4.0, 4.5, 5.0, 5.5, 6.0 and 6.7) on the spore germination of Gleichenella pectinata. To accomplish this, the spores were surface sterilized and sown in bottles containing mineral medium. The spores of G. pectinata are monolets and the perispore surface can show large and irregular deposits. During germination, filamentous gametophytes with and without developing rhizoids were observed. Only gametophytes which presented developed rhizoids were able to reach the heart-shaped developmental stage. Based on the collection, the rate of and gametophyte development were generally very low. The relative germination rates were higher at $25^{\circ} \mathrm{C}$ than at $30{ }^{\circ} \mathrm{C}$. Moreover, the highest percentages of gametophytes with developed rhizoids were observed at 22 and $5 \%$ of natural light $(8.8 \pm 2.3 \%$ and $11.3 \pm 2.2 \%$ respectively) and the highest percentage of heart-shaped gametophytes were observed at $\mathrm{pH} 4.5$ and 5.0 (1.2 $\pm 0.8 \%$ and $2.2 \pm 0.8 \%$, respectively).
\end{abstract}

Key words: Gleichenella pectinata, germination, light, $\mathrm{pH}$, temperatures

\section{INTRODUCTION}

Both the degradation of forest fragments and posterior regeneration during the succesional stages lead to increased soil erosion and leaching of mineral nutrients. However, some species of the fern family Gleicheniaceae are resurgent during the natural regeneration of degraded areas and could, therefore, be used as part of the plant covering in restoration projects, mainly of hillsides and slopes. According to Heinrich (1986), some ferns belonging to the Pteridium
(Dennstaedtiaceae) and Gleichenella (Gleicheniaceae) genera, are found growing in degraded forest fragments in some Brazilian regions. Reis et al. (1999) reported that Gleichenella pectinata (Willd) Ching was one of the first species to colonize degraded areas. The Gleicheniaceae family (Polypodiopsida, Gleicheniales) (Smith et al. 2006) presents five genera and 120 to 140 species of pantropical distribution. Four genera occur in the Americas and are represented by 40 to 50 species (Ostergaard-Andersen and Ollgarard 2001).

\footnotetext{
*Author for correspondence: amrandi@ccb.ufsc.br
} 
Gleichenella genus is geographically distributed from southern Mexico and the Antilles to Chile, Argentina, Uruguay and Brazil (Tryon and Tryon 1982, Prado 2004). According to Queiroz (1994), Gleichenella pectinata (Willd) Ching (Prado 2004, Prado 2005) forms associations called Gleichenietum pectinata or "gleichenietum" characterized by the strong predominance of this species (Queiroz 1994). Frequently, these associations survive for several years growing in abrupt declivities on roadsides and in steep slopes where G. pectinata is easily identified for the identical ramifications and number of pinnas. As such, G. pectinata is probable the most frequent species in southern Brazil (Sehnem, 1977). The germination of fern spores and the gametophyte development are strongly controlled by the light, mineral nutrition and temperature. Photosensitive spores need mild temperatures for the inductive processes (Towill 1978, Chen and Ikuma 1979, Haupt 1990, 1991, 1992, Fernández et al. 1996, 1997). According to Camloh and Gogola (1992) and Camloh (1993, 1999), liquid media are superior to solid media for early gametophyte development. Camloh (1993) and Simabukuro et al. (1998) also pointed out the necessity of spore sterilization before its inoculation in "in vitro"procedures.

Therefore, the aim of this paper was to identify the optimal ecophysiological conditions for spore germination of Gleichenella pectinata (Willd.) Ching.

\section{MATERIAL AND METHODS}

Fertile leaves of several "gleichenietos" were collected in March, April, May and November of 2004, as well as December of 2005 in the "Unidade de Conservação Ambiental Desterro" (UCAD), situated between $27^{\circ} 30^{\prime} 48^{\prime \prime}$ to $27^{\circ} 32^{\prime} 34^{\prime \prime}$ $\mathrm{S}$ and $48^{\circ} 29^{\prime} 38^{\prime \prime}$ to $48^{\circ} 30^{\prime} 42^{\prime \prime} \mathrm{W}$ in Florianópolis, Island of Santa Catarina, State of Santa Catarina State, Brazil (Ladwig 1998). The collection site was a 491-ha natural Atlantic forest fragment. Sporophylls were dried at $30^{\circ} \mathrm{C}$ for three days on filter paper in order to induce the dehiscence. The spores were removed and separated from the debris by filtering through lens paper, then stored in glass jars under refrigeration at $7 \pm 1^{\circ} \mathrm{C}$.

The spores of Gleichenella pectinata were surface sterilized using a $10 \%(\mathrm{v} / \mathrm{v})$ solution of commercial bleach ( $2 \%$ of active chlorine) for 15 min. before filtering through sterile filter paper and washed several times with sterile distilled water. The spores were sown in conical flasks containing $20 \mathrm{~mL}$ of Mohr's nutrient media solution (Dyer 1979), supplemented with Benomyl $0.01 \%$ or they were inoculated in four Petri dishes, with $20 \mathrm{~mL}$ of nutrient media solidified with $0.8 \%$ Agar. The flasks were plugged with two layers of autoclaved transparent commercial polypropylene film $(7 \times 7 \mathrm{~cm})$ and fixed with a rubber band. All the procedures were carried out in a laminar hood. Because a preliminary study showed that there was no difference in spore germination between liquid media and solidified media the liquid media was used in this work.

To study the effects of light levels on the germination of $G$. pectinata, trays containing conical flasks in which surface sterilized spores were sown, were kept in $50 \mathrm{~cm}^{3}$ boxes covered with black shade net to provide $62,42,22$ and $5 \%$ of light. A maximum and minimum thermometer was placed inside the boxes. The irradiance levels inside the boxes were measured daily using a quantameter LICOR 250, equipped with a PAR sensor (400 to $700 \mathrm{~nm}$ ), periodically at $2 \mathrm{PM}$, except on rainy days. On a typical sunny March day, the density of photon flux reached 1400 4mol. $\mathrm{m}^{-2} \cdot \mathrm{s}^{-1}$ in Florianópolis, SC. Using the spores collected in November 2004, which showed higher germination rates than the spores collected in the other months, the test was conducted in October 2005. The effects of different temperatures $\left(25\right.$ and $\left.30 \pm 1{ }^{\circ} \mathrm{C}\right)$ and $\mathrm{pH}$ values (4.0, 4.5, 5.0, 5.5, 6.0 and 6.7- control) were studied in a growth chamber, at a photon flux density of $30 \mu \mathrm{mol} \mathrm{m} \mathrm{m}^{-2} \mathrm{~s}^{-1}$ and a 16-h photoperiod. The effects of different $\mathrm{pH}$ values were determined at $25 \pm 1^{\circ} \mathrm{C}$.

Dry spore samples were transferred to the stubs and then gold-coated with $20 \mathrm{~nm}$ of gold in a Baltec-CED 030. Examination was performed with a Philips-XL 30 scanning electron microscope. Specimens were collected after 14, 34 and 48 days of spore inoculation in the mineral solution. For light microscopy (LM), gametophytes were fixed in $2.5 \%$ glutaraldeyde in $0.1 \mathrm{M}$ sodium phosphate buffer at a $\mathrm{pH}$ of 7.2 (Bozzola and Russel 1991). All the samples were fixed in Eppendorf tubes for 3h, centrifuged for 3 min, dehydrated with an ethanol series and then stored in ethanol. The samples were mounted on 
glass slides with ethanol and photographed with a Leika-MPS 30 light microscope.

Data were analyzed by Excel and BioEstat for Windows. For each treatment, eight slides (8 replications) with 100 specimens each were analyzed. Gametophytes which showed chlorosis were considered dead. The results expressed as percentages were arcsine transformated. An ANOVA analysis of variance followed by a Tukey test was applied to normal homoscedastic data. A Kruskal-Wallis test $(H)$ followed by the Dunn test was performed whenever data did not show normality or homogeneity of variances, after angular transformations and the Stendent's $t$ test was performed to compare two means (Santana and Ranal 2004, Zar 1999).

\section{RESULTS}

The spores of G. pectinata (Fig. 1) were monolete, ellipsoidal and reniform, presenting a prominent scar, and the perispore surface was smooth or partially irregular and showed large and irregular deposits as described by Prado (2005). The spores considered unviable were transparent and did not present any storage substance, whereas the spores considered viable were partially or totally filled with reserve grains and showed an opaque aspect (Fig. 2). Three classes of developmental stages were observed after the spore germination: spores with chloroplasts, but without rhizoids (Fig. 3), filamentous gametophytes without developed rhizoids (Fig. 4) and filamentous gametophytes with developed rhizoids (Fig. 5). After 34 days of spore cultivation, some gametophytes remained filamentous and others presented a spatulated protallus (Fig. 6). After 48 days, some gametophytes were heart-shaped (Fig. 7). Only gametophytes which presented developed rhizoids were able to reach the heart-shape. Reproductive structures were not observed during the period of gametophyte cultivation. Table 1 shows the time of spore storage under refrigeration and the percentages of gametophytes with developed rhizoids, without rhizoids and viable spores of $G$. pectinata.
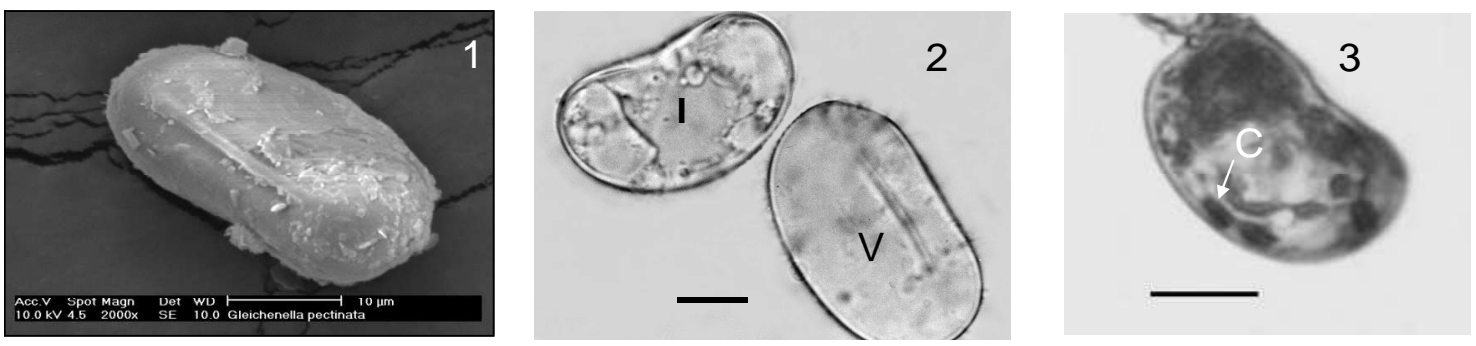

Figure 1 - Spore of Gleichenella pectinata under SEM (Bar $=20 \mu \mathrm{m})$. Figure 2- Spore of Gleichenella pectinata under LM. I -unviable; V- viable (Barras $=10 \mu \mathrm{m})$. Figure 3Spores of Gleichenella pectinata after 14 days of cultivation; the arrow indicate starch grains stained with lugol inside chloroplasts ; c- chloroplast $($ Bar $=20 \mu \mathrm{m})$.

Table 1 - Percentage of gametophytes with developed rhizoid, without rhizoid and viable spores of Gleichenella pectinata (Willd.) Ching collected in 2004.Columns with different letters denote statistical differences (Dunn tests). $\mathrm{n}=32, \mathrm{a}=0.05, \mathrm{~d}=0.5$.

\begin{tabular}{|c|c|c|c|c|}
\hline Collection & $\begin{array}{c}\text { Storage at } 7 \pm 1^{\circ} \mathrm{C} \\
(\text { Months) }\end{array}$ & $\begin{array}{l}\text { Gametophytes with } \\
\text { developed rhizoids }\end{array}$ & $\begin{array}{l}\text { Gametophytes without } \\
\text { developed rhizoids }\end{array}$ & $\begin{array}{l}\text { Viable } \\
\text { spores }\end{array}$ \\
\hline & & \multicolumn{3}{|c|}{$\%($ Mean \pm standard deviation $)$} \\
\hline March & 2.8 & $4.4 \pm 2.7 \mathrm{~b}$ & $53.6 \pm 17.3 \mathrm{a}$ & $89.2 \pm 2.4 \mathrm{a}$ \\
\hline April & 2.4 & $2.8 \pm 3.1 \mathrm{~b}$ & $48.5 \pm 6.4 \mathrm{a}$ & $83.1 \pm 7.6 \mathrm{a}$ \\
\hline May & 1.6 & $1.5 \pm 1.0 \mathrm{~b}$ & $52.8 \pm 4.3 \mathrm{a}$ & $55.9 \pm 6.7 b$ \\
\hline November & 11.0 & $18.2 \pm 3.5 \mathrm{a}$ & $3.5 \pm 2.0 \mathrm{~b}$ & $61.1 \pm 10.2 b$ \\
\hline \multicolumn{2}{|r|}{$H$} & 16.73 & 14.97 & 22.84 \\
\hline
\end{tabular}



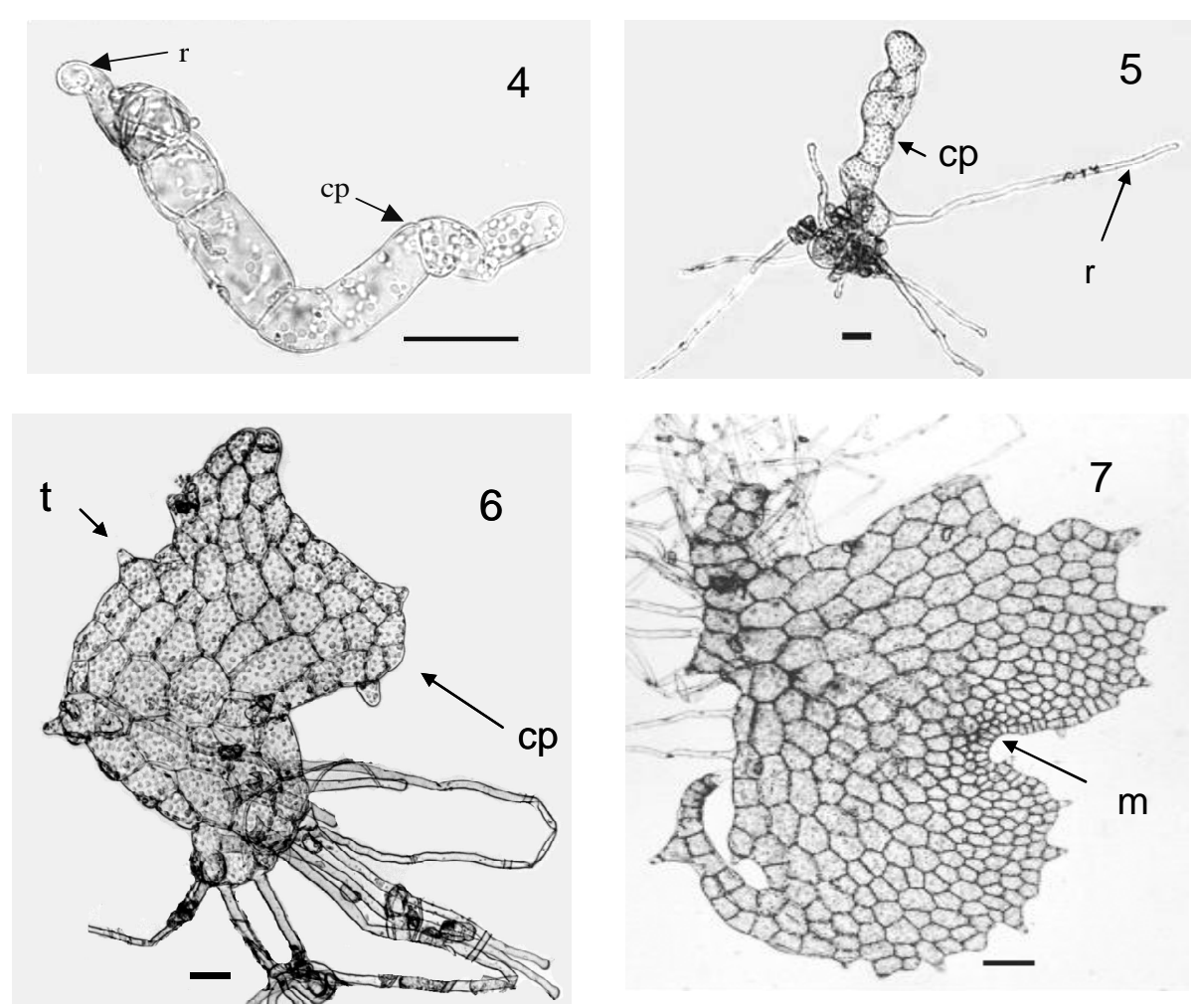

Figura 4 - Filamentous gametophyte of Gleichenella pectinata without developed rhizoid after 34 days of cultivation $(\mathrm{Bar}=50 \mu \mathrm{m}, 20 \mathrm{x})$. Figure 5 - Filamentous gametophyte of Gleichenella pectinata with developed rhizoid after 34 days of cultivation (Bar = $50 \mu \mathrm{m})$. Figure 6 - Spatulate gametophyte $($ Bar $=50 \mu \mathrm{m})$. Figure 7- Heartshaped gametophyte after 48 days of cultivation $($ Bar $=50 \mu \mathrm{m})$. r-rhizoid , t- trichome, $\mathrm{cp}$ protonemal cell, m- apical meristem.

The highest percentage of gametophytes with developed rhizoids and the lowest percentage of gametophytes without rhizoids were observed in spores collected in November 2004. There was no statistical difference between the percentages of gametophytes with developed rhizoids in the spores collected in March, April and May 2004. The highest percentages of viable spores were observed in the collection of March and April 2004, which showed a low germination percentage. Therefore, spores collected in May presented a low percentage of viable spores and an extremely low germination percentage. However, the percentage of viable spores collected in November 2004 was also lower than the percentage of viable spores collected in March and April, and similar to those collected in May 2004.
A temperature of $30{ }^{\circ} \mathrm{C}$ partially inhibited the germination of $G$. pectinata (Table 2). The lowest percentage of gametophytes with developed rhizoids was observed in $62 \%$ of sunlight; the highest percentage of gametophytes with developed rhizoids was found for the spores that germinated in $5 \%$ of sunlight. The maximum temperatures inside the boxes ranged from 30 to $40^{\circ} \mathrm{C}$ and minimum temperatures ranged from 12 to $19^{\circ} \mathrm{C}$ (Fig. $8 \mathrm{~A}$ ). The minimum irradiances inside boxes ranged from 15 to $107 \mu \mathrm{mol}$ $\mathrm{m}^{-2} \mathrm{~s}^{-1}$, while the maximum irradiances ranged from 77 to $553 \mu \mathrm{molm}^{-2} \mathrm{~s}^{-1}$ (Fig. 8B). During this period, the days were generally rainy, and the highest irradiances were registered in October 19 and 22. 
No statistical differences were observed between the percentages of gametophytes with and without developed rhizoids of G. pectinata, in all the $\mathrm{pH}$ values analyzed. The percentages of heart-shaped. gametophytes were very low for all of the $\mathrm{pH}$ values studied, but the highest gametophyte production was found at $\mathrm{pH} 5.0$, which did significantly differ from the $\mathrm{pH} 4.5$ (Table 3 ).

Table 2 - Effect of temperature on gametophytes with developed rhizoids and without developed rhizoids of Gleichenella pectinata (Willd.) Ching from spores collected in November (2004), stored at $7 \pm 1^{\circ} \mathrm{C}$ for 11 month. Columns with different letters denote statistical differences (Student's $t$ test).

\begin{tabular}{ccc}
\hline Treatment & $\begin{array}{c}\text { Gametophyte with developed } \\
\text { rhizoids }\end{array}$ & $\begin{array}{c}\text { Gametophytes without developed } \\
\text { rhizoids }\end{array}$ \\
\hline Temperature $\left({ }^{\circ} \mathrm{C}\right)$ & \multicolumn{2}{c}{$\%$ (Mean \pm standard deviation) } \\
25 & $18.2 \pm 3.5 \mathrm{a}$ & $16.58 \pm 5.17 \mathrm{a}$ \\
30 & $4.8 \pm 3.4 \mathrm{~b}$ & $14.21 \pm 9.6 \mathrm{a}$ \\
$t$ & 6.6 & 0.49 \\
\hline
\end{tabular}

Table 3 - Effect of light levels on gametophytes with developed rhizoids and whithout developed rhizoids of Gleichenella pectinata (Willd.) Ching from spores collected in November (2004), stored at $7 \pm 1^{\circ} \mathrm{C}$ for 11 month. Columns with different letters denote statistical differences (Tukey).

\begin{tabular}{ccc}
\hline $\begin{array}{c}\text { Light level } \\
\text { (\% of sunlight) }\end{array}$ & $\begin{array}{c}\text { Gametophytes with developed } \\
\text { rhizoids }\end{array}$ & Gametophytes without developed rhizoids \\
\hline \multicolumn{3}{c}{$\%$ (Mean \pm standard deviation) } \\
42 & $0.5 \pm 0.7 \mathrm{c}$ & $4.5 \pm 3.7 \mathrm{a}$ \\
22 & $6.2 \pm 2.3 \mathrm{~b}$ & $7.8 \pm 1.8 \mathrm{a}$ \\
5 & $8.8 \pm 2.3 \mathrm{a} \mathrm{b}$ & $6.9 \pm 5.5 \mathrm{a}$ \\
$F$ & $11.3 \pm 2.2 \mathrm{a}$ & $8.2 \pm 5.3 \mathrm{a}$ \\
& 31.50 & 0.86 \\
\hline
\end{tabular}

Table 4 - Effect of pH on gametophytes with developed rhizoids and total gametophytes of Gleichenella pectinata (Willd.) Ching from spores collected in December (2005), stored at $7 \pm 1^{\circ} \mathrm{C}$ for 04 months. Columns with different letters denote statistical differences (Tukey test).

\begin{tabular}{cccc}
\hline pH & $\begin{array}{c}\text { Gametophyte with } \\
\text { developed rhizoids }\end{array}$ & $\begin{array}{c}\text { Heartshaped } \\
\text { gametophytes }\end{array}$ & $\begin{array}{c}\text { Gametophyte without } \\
\text { developed rhizoids }\end{array}$ \\
\hline 4.0 & $6.8 \pm 2.3 \mathrm{a}$ & $0.8 \pm 0.4 \mathrm{~b}$ (mean \pm standard deviation) \\
4.5 & $9.2 \pm 7.3 \mathrm{a}$ & $1.2 \pm 0.8 \mathrm{ab}$ & $21.2 \pm 5.5 \mathrm{a}$ \\
5.0 & $13.5 \pm 10.4 \mathrm{a}$ & $2.2 \pm 0.8 \mathrm{a}$ & $26.7 \pm 8.9 \mathrm{a}$ \\
5.5 & $9.7 \pm 2.9 \mathrm{a}$ & $0.8 \pm 0.4 \mathrm{~b}$ & $22.3 \pm 5.9 \mathrm{a}$ \\
6.0 & $6.3 \pm 3.8 \mathrm{a}$ & $0.5 \pm 0.5 \mathrm{~b}$ & $20.5 \pm 2.7 \mathrm{a}$ \\
Control (6.7) & $4.5 \pm 4.8 \mathrm{a}$ & $0.3 \pm 0.5 \mathrm{~b}$ & $22.5 \pm 2.7 \mathrm{a}$ \\
$H$ & 6.84 & 7.5574 & 1.2587 \\
\hline
\end{tabular}



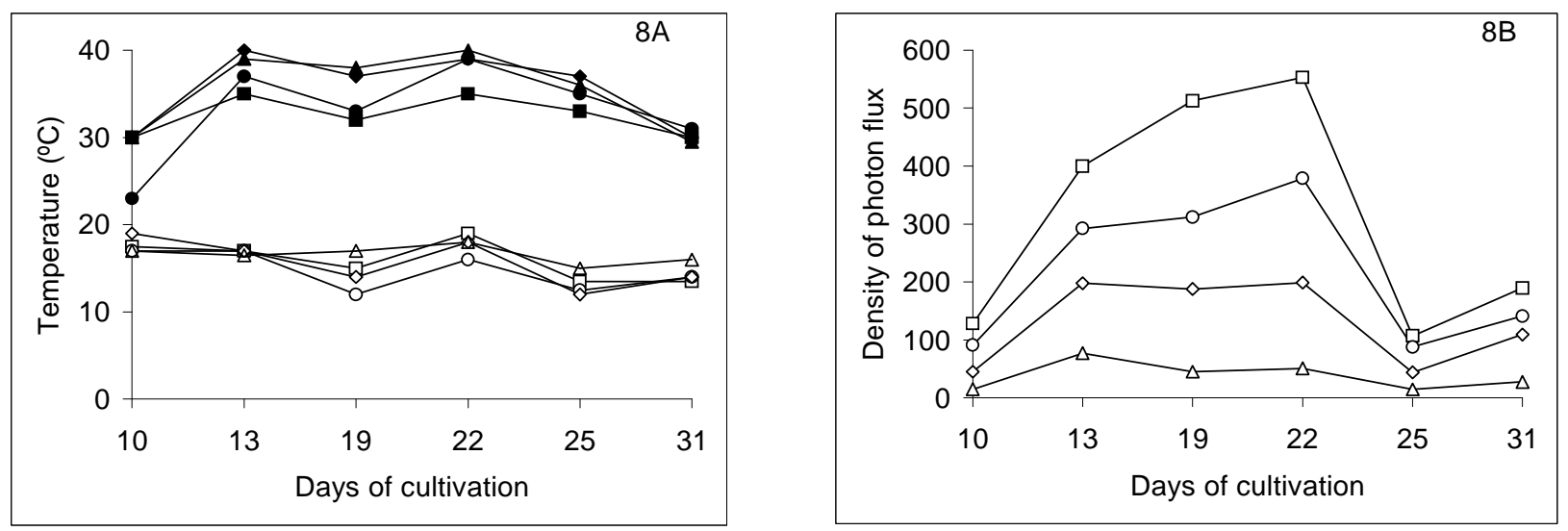

Figure 8 - Minimum and maximum temperatures (8A) and density of photon flux $\left(\mu \mathrm{mol} \mathrm{m} \mathrm{m}^{-2}\right)$ (8B) measured at $2 \mathrm{pm}$ during the month of October 2005 inside black shade netting boxes. Empty symbols are minimum temperatures and full symbols are maximum temperatures (8A). $\square$ - 62\% light - O- 42\% light;- $\diamond$-, $22 \%$ light;- $\Delta$ - 5\% light.

\section{DISCUSSION}

As noted above, three classes of developmental stages were observed after the germination of spore: spores with chloroplasts, but without rhizoids, filamentous gametophytes without developed rhizoids and filamentous gametophytes with developed rhizoids. The first class of development of $G$. pectinata seemed to be similar to the dark germination of Tmesipteris tannensis (Spreng.) Bernh., T. elongata Dang. and Psilotum $\mathrm{x}$ intermedium Wagner (Psilotaceae), all of which produced proplastides, but without diferentiation of rhizoids (Whittier and Braggins 1993). This suggested the inhibition of spore germination and rhizoid development.

Both phenomena could be explained by the fact that not all spores considered viable were capable of germinating and that gametophytes without developed rhizoids were incapable of reaching the heart-shape and died during the cultivation. It could also be possible that the production of viable spores was influenced by the seasonal alterations, such as temperature, photoperiod and rainy or dry periods. In Adiantum capillus veneris $\mathrm{L}$. (Pteridaceae) the first mitosis is induced by the red light, through the phytochrome system, and the spore nucleus migrates to the spore aperture. However, if this movement is inhibited, the rhizoid does not differentiate.

Indeed, the second mitosis is induced by the blue light, but is inhibited by the red light (Furuya et al.
1997; Uchida and Furuya 1997). Moreover, during the course of this study, it was found that the spores which were collected in November 2004, and which were stored over the course of 11 months under refrigeration, showed the highest percentages of gametophyte with developed rhizoids. In this case, it was possible that the dry storage under low temperatures, promoted the germination of spores of G. pectinata. Data also showed variation in spore viability, total gametophytes and gametophytes with developed rhizois among the different collections. This was supposed by Sheffield et al. (2001) who reported the species - ecotype - specific germination of fern spores in liquid mineral medium. This means that the same species could show different germinative potential depending on local collection, period of collection and time of spore storage in refrigeration.

Peres et al. (1998) and Soares et al. (2000) observed that the leaf extracts of G. pectinata and other Gliecheniaceae collected in different seasons of the year produced fenolic compounds that presented allelopathic activity. Auto-allelopathy or auto-toxicity occurs when a plant produces toxic substances that inhibit the germination and the growth of the same species (Waller et al. 1986). These extracts delayed and inhibited the germination of Lactuca sativa L. (Asteraceae) and Clidemia hirta (L.) D. Don (Melastomataceae), and reduced the cellular length of plantlet hypocotyls, also suggesting the inhibition of 
cellular divisions. Depending on the season of leaf collection and age of the leaf, they have demonstrated that extracts could induce or inhibit these seed germinations. Therefore, the allelopathic substances could also be produced by the own spores and by young gametophytes of $G$. pectinata cultivated "in vitro" causing autoallelopathy or auto-toxicicity and, finaly, resulting in gametophytes without developed rhizoids.

$G$. pectinata showed the highest germination percentage from 5 to $20 \%$ of sunlight. Similar effects of light were found in the spores of Dicksonia sellowiana Hook (Dicksoniaceae), Rumohra adiantiformis (Forst.) Ching (Dryopteridaceae), Cyathea delgadii Sternb. (Cyatheaceae), Blechnum brasiliense Desv. (Blechnaceae) and Polypodium lepidopteris (Langsd. and Fisch.) Kunze (Pteridophyta, Polypodiaceae) (Filippini et al 1999, Renner and Randi 2004, Brum and Randi 2002, Hiendlmayer and Randi 2007, Viviani and Randi 2008). According to Haupt $(1990,1991,1992)$ and Raghavan (1989) high temperatures seem to inhibit the gene expression and protein synthesis mediated by phytochrome during fern spore germination. In the present work, the germination of G. pectinata was partially inhibited at $30^{\circ} \mathrm{C}$.

For $R$. adiantiformis and $P$. lepidopteris, the germination was also partially inhibited at $30{ }^{\circ} \mathrm{C}$ (Brum and Randi 2002, Viviani and Randi 2008). Similar results were observed by PerezGarcía and Riba (1982) with some tree ferns: Lophosoria quadripinnata (Gmel.) C. Chr (Lophosoriaceae), Trichipteris bicrenata (Liebm) Tryon, T. scabriuscula (Maxon) Tryon, Nephelea mexicana (Schl. and Cham.) Tryon and Cyathea fulva (Mart.and the Gal.) (Cyatheacea). Ranal (1999) worked with several fern species of the mesophytic semideciduous forest of S. Paulo State and observed that the highest germinability was generally found between 21 and $29^{\circ} \mathrm{C}$.

High daily fluctuations in the minimum and maximum temperatures were observed inside the boxes covered with the black shade net during October 2005. Such oscillations were probably a consequence of the air circulation in windy days, considering that the box receiving $62 \%$ of sunlight was more ventilated than the others, due to the larger size of holes in the black shade net. The boxes receiving lower light levels reached the highest temperatures $\left(40{ }^{\circ} \mathrm{C}\right)$ probably due to less ventilation. However, the highest percentages of gametophytes with developed rhizoids were found under the lower light levels. Daily temperature alternation associated with the low levels of light seems to be beneficial for the germination of this species in this environment. Similar results were also found by Hiendlmayer and Randi (2007) for $B$. brasiliense and $C$. delgadii.

Nondorf et al. (2003) reported that the optimal conditions for spore germination were often a reflection of optimal growth conditions for the entire life cycles of ferns. However,as noted above, G. pectinata could grow, even in the degraded fragments of forests, where light incidence was intense and where mineral nutrition and water were limiting factors. Thus, in its natural habitat, possibly, a very low percentage os spores very low percentage of spores of $\mathrm{G}$. pectinata would be able to germinate, but only during the rainy periods, with exposure to low light, moderate temperatures and just enough water retention in the soil pores to make the gametophyte development and sporophyte formation possible.

The present data aggreed with the literature, for the spores of several ferns, which showed high germination percentages in acid or neutral $\mathrm{pH}$ conditions (Miller 1968). Nevertheless, the spores of some species are not able to germinate in strong acid conditions or show very low germination percentage (Hevly 1963, Mohr 1956). In other species, moderate germination levels occur, but the gametophyte development is quite limited where $\mathrm{pH}$ are low (Courbet 1955, Otto et al. 1984). On the other hand, the spores of Ophioglossum palmatum L. germinate better in strong acid conditions, and the germination is reduced or eliminated in acid or slightly neutral conditions (Whittier 1981,Whittierand and Moyroud 1993). For the spores of Cheilanthes feei T. Moore (Polypodiaceae), higher germination percentages were observed in acidic $\mathrm{pH}$ ( 4.5 and 5.5) (Nondorf et al. 2003). This work showed that the germination percentage of $G$. pectinata spores was very low in comparison to several other fern species that could reach around $100 \%$ of spore germination as reported by Gomes et al (2006) for spores of Dicksonia sellowiana Hook. (Dicksoniaceae). Besides the low germination percentage, gametophytes without developed rhizoids are not able to grow and only gametophytes with developed rhizoids continue their development and reach the heart-shape. Therefore, the production of sporophytes through spore cultivation is extremely low. Consequently, 
we suggest alternative methods of vegetative and in vitro culture in order to obtain sporophytes of G.pectinata.

\section{ACKNOWLEDGEMENTS}

Débora Rosana Marques Lehmann thanks CAPES (Coordenação de Aperfeiçoamento de Pessoal de Nivel Superior) for the MSc grant, and Áurea Maria Randi thanks CNPq (Conselho Nacional de Desenvolvimento Científico e Tecnológica) for the research grant (level 2).

\section{RESUMO}

A finalidade deste estudo foi analisar o potencial germinativo dos esporos de $G$. pectinata e verificar os efeitos de níveis de luz $(62,42,22$ e $5 \%$ da luz natural), das temperaturas de 25 e $30^{\circ} \mathrm{C}$ e de pHs entre 4,0 e 6,7 na germinação. Esporos de $G$. pectinata são monoletes e a superfície apresenta depósitos grandes e irregulares. Observamos três classes de desenvolvimento: esporos contendo cloroplastos, gametófitos filamentosos sem rizóides desenvolvidos e gametófitos filamentosos com rizóides desenvolvidos. Somente os gametófitos com rizóides desenvolvidos foram capazes de alcançar a fase cordiforme. As porcentagens de germinação foram mais elevadas à temperatura de $25^{\circ} \mathrm{C}$ do que $30{ }^{\circ} \mathrm{C}$. As mais elevadas porcentagens de gametófitos com rizóides desenvolvidos foram observadas sob 22 e $5 \%$ da luz natural e as porcentagens mais elevadas de gametófitos cordiformes foram observadas no $\mathrm{pH} 5,0$.

\section{REFERENCES}

Brum, F. M. R. and Randi, A. M. (2002), High irradiance and temperature inhibit the germination of spores of the fern Rumohra adiantiformis (Forst.) Ching (Dryopteridaceae). Rev Bras Bot 25: 391-396.

Camloh, M. and Gogala, N. (1992), In vitro culture of Platycerium bifurcatum gametophytes. Sci Hortic 51: 343-346.

Camloh, M. (1993), Spore germination and early gametophyte development of Platycerium bifurcatum. Am Fern J 83: 79-85.
Camloh, M. (1999), Spore age and sterilization affect germination and early gametophyte development of Platycerium bifurcatum. Am Fern J 89: 124-132.

Chen, C. and Ikuma, H. (1979), Photocontrol of the germination of Onoclea spores. Plant Physiol 63:704708.

Courbet, H. (1965), Influence de la concentration ionique du milieu sur la germination des spores et la croissance des prothalles de Filicales culture aseptique. Cr Acad Sci 241:441-443.

Cusatis, A. C. (2001). Diagnósticos de taludes rodoviários revegetados naturalmente na região de Viçosa, MG. Dissertação de Magister Scientiae. Universidade Federal de Viçosa, Viçosa.

Dyer, A. F. (1979), The culture of fern gametophytes for experimental investigation. In- The experimental biology of ferns, ed. A.F. Dyer. Academic Press, London, pp. 253-305.

Esteves, L. M. and Felippe, G. M. (1985), Fotossensibilidade de esporos de pteridófitas dos cerrados. Rev Bras Bot 8:219-22.

Fernández, H.; Bertrand, A .M. and Tamés, R. S. (1996), Influence of tissue culture conditions on apogamy in Dryopteris affinis sp affinis. Plant Cell Tiss Org 44:261-265.

Fernández, H.; Bertrand, A. M. and Tamés, R. S. (1997), Micropropagation and phase change of Blechnum spicant and Pteris ensiformis. Plant Cell Tiss Org 45:93-97.

Filippini, E .C. P.; Duz, S. R.and Randi, A. M. (1999), Light and storage in the germination of spores of Dicksonia selowiana (Presl.) Hook., Dicksoniaceae. Rev Bras Bot 22: 21-26.

Furuya, M.; Kanno, M.; Okomoto, H.; Fukuda, S. and Wada, M. (1977), Control of mitosis by phytochrome and blue-light receptor in fern spore. Plant Physiol 13: 677-683.

Gomes, G. S. ; Randi, A.M.; Puchalski, A.; Santos, D.S. and Reis, M.S (2006), Variability in the germination of spores among and within natural populations of the endangered tree fern Dicksonia sellowiana Hook. (Xaxim). Braz Arch Biol Techn 49: 1-10.

Haupt, W. (1990), Phytochrome-mediated fern-spore germination: inhibition by elevated temperatures. Photochem Photobiol 52: 57-59.

Haupt, W. (1991), Phytochrome-controlled fern-spore germination: phase-specific modulation by elevated temperatures. Photochem Photobiol 54: 811-818.

Haupt, W. (1992), Phytochrome-mediated fern-spore germination: a temperature-sensitive phase in the transduction chain after action of Pfr. J Plant Physiol 140: $575-581$. 
Hiendlmeyer, R. and Randi. A. M. (2007), Response of spores and young gametophytes of Cyathea delgadii Sternb. (Cyatheaceae) and Blechnum brasiliense Desv. (Blechnaceae) to different light levels. Acta Bot Bras 21: 909 - 915.

Heinrich, W. (1986), Vegetação e Zonas Climáticas: Tratado de Ecologia Global. Editora Pedagógica e Universitária. São Paulo.Hevly, R. H. (1963), Adaptations of cheilanthoid ferns to desert environments. J Arizona Acad Sci 2: 164- 175.

Kanno, M.; Okomoto, H.; Fukuda, S. and Wada, M. (1997), Control of mitosis by phytochrome and a blue-light receptor in fern spore. Plant Physiol 13: 677-683.

Ladwig, N.I. (1998), As Unidades de Conservação Ambiental e o Cadastro Técnico Multifinalitário. Estudo de Caso: UCAD/UFSC (Unidade de Conservação Ambiental Desterro) Dissertação de Mestrado. Universidade Federal de Santa Catarina, Florianópolis.

Millër, J. H. (1968), Fern gametophytes as experimental material. Botanical Review 34:361-440.Mohr, H. (1956), Die Abhängikeit des Protonemapolarität bei Farnen von Licht. Planta 47:127-158.

Nondorf, S. L.; Dooley, M. A.; Palmieri, M. and Swatzell, L. J. (2003), The effects of $\mathrm{pH}$, temperature, light intensity, light quality, and moisture levels on spore germination in Cheilanthes feei of Southeast Missouri. Am Fern J 93:56-69.

Ostergaard-Andersen, E. and Ollgarrd, B. (1996), A note on some morphological terms of the leaf in the Gleicheniaceae. Am Fern J 86:52-57.

Ostergaard-Andersen, E. and Ollgarrd, B. 2001, Gleicheniaceae. In Flora of Ecuador, eds. G. Haarling and L. Andersson, University of Göteborg, Göteborg, pp. 103-169.

Otto, E. T.; Crow, J. H and Kirby, E. G. (1984), Effects of acidic growth conditions on spore germination and reproductive development in Dryopteris marginalis (L.). Ann Bot 53:439-442.

Peres, M. T. L.; Pizzolatti, M. G. and Yunes, R. A. (1998), Potencial de atividade alelopática de Gleichenia pectinata Willd (Pr.). Pesqui Agropecu Bras 33:131-137.

Pérez-Garcia, B. and Riba, R. (1982), Germinacion de esporas de Cyatheaceae bajo diversas temperaturas. Biotropica 14:281-287.

Prado, J. 2004, Criptógamos do Parque Estadual das Fontes do Ipiranga, São Paulo, SP. Pteridophyta: 8. Gleicheniaceae. Hoehnea 31:33-37.

Prado, J. 2005, Flora da Reserva Ducke, Amazonas, Brasil: Pteridophyta- Gleicheniaceae. Rodriguésia 56:53-55.
Queiroz, M. H. De. 1994, Approche phytoécologique et dynamique des formations végétales secondaires développées après abandon des activités agricoles, dans le domaine de la Forêt Ombrophile dense de versant (Forêt Atlantique) à Santa Catarina-Brésil. Thèse de Doctorat. École Nationale du Génie Rural des Eaux et de Forêts. Nancy.

Raghavan, V. (1989), Developmental biology of fern gametophytes. University Press. Cambridge

Ranal, M. A. (1999), Effects of temperature on spore germination in some fern species from semideciduous mesophytic forest. Am Fern J 89:149-158.

Reis, A.; Zambonin, R. M. and Nakazono, E. M. (1999), Recuperação de áreas de florestas degradadas utilizam a sucessão $e$ as interações plantas-animais, Caderno $\mathrm{n}^{\circ} 14$., Reserva da Biosfera da Mata Atlântica. São Paulo

Renner, G. D. R. and Randi, A. M. (2004), Effect of sucrose and irradiance on germination and early gametophyte growth of the endangered tree fern Dicksonia sellowiana Hook (Dicksoniaceae) Acta Bot Bras 18:375-390.

Santana D. G. and Ranal M. A. (2004), Análise da germinação: um enfoque estatístico. Editora UnB, Brasília.

Simabukuro, E. A, Dyer, A. F. and Felippe, G. M. (1998), The effect of sterilization and storage conditions on the viability of spores of Cyathea delgadii. Am Fern J 88:124-132

Sehnem, A. (1977), As filicíneas do Sul do Brasil, sua distribuição geográfica, sua ecologia e suas rotas de migração. Pesquisas Botânicas 31: 1-108.

Sheffield, E., Douglas, G. E., Hearne, S. J., Huxham, S. and Wynn, J. M. (2001), Enhancement of fern spore germination and gametophyte growth in artificial media. Am Fern J 91:179-186.

Soares, G. L. G. and Vieira, T. R. (2000), Inibição da germinação e crescimento radicular de alface (cv. "Grand Rapids") por extratos aquosos de cinco espécies de Gleicheniaceae. Floresta e Ambiente 7:180-197.

Smith, A.R., Pryer, K.M., Schuettpelz, E. Korall, P., Schneider, H and Wolf, P.G. 2006, A classification for extant ferns. Taxon 55: 705-731.

Towill, L. R. (1978), Temperature and photocontrol of Onoclea spore germination. Plant Physiol 62:116119.

Tryon, M. R. and Tryon, A. F. (1982), Fern and allied plants with special reference to Tropical America. Springer-Verlag, New York. 
Uchida, K. and Furuya, M. (1997), Control of the entry into $\mathrm{S}$ phase by phytochrome and blue light receptor in the first cell cycle of fern spores. Plant Cell Physiol 38:1075-1079.

Waller, G.R., Kumari, D., Friedeman, J., Friedeman, N. and Chou, D.H. 1986, Caffeine autotoxicity in Coffea arabica L. In "The Science of allelopathy, eds. A.R. Putnam and T. Chung-Shih. John Wiley, New York, pp. 243-269.

Viviani, D. and Randi, A. M. (2008), Effects of pH, temperature and light intensity on spore germination and growth analysis of young sporophytes of Polypodium lepidopteris (Langsd. and Fisch.) Kunze (Pteridophyta, Polypodiaceae). Rodriguésia 59:435444.

Whittier, D. P. (1981), Spore germination and young gametophyte development of Botrychium and Ophioglossum in axenic culture. Am Fern J 71:13-19.
Whittier, D. P. and Braggins, J. E. (1993), Spore germination in the Psilotaceae. Can J Bot 72:688692.

Whittier, D. P. and Moyroud, R. (1993), The promotion of spore germination and gametophyte development in Ophioglossum palmatum by low pH. Am Fern J 83:41-46.

Zar, J.H. 1999, Biostatistical analysis. Prentice-Hall, New Jersey.
Received: April 22, 2009; Revised: November 05, 2009; Accepted: July 08, 2010. 